\title{
PROSES FONOLOGIS DALAM PENGADOPSIAN KATA BAHASA INDONESIA KE DALAM BAHASA CIACIA DI KABUPATEN BUTON, SULAWESI TENGGARA
}

\author{
Dianita Indrawati \\ Universitas Negeri Surabaya \\ Email: dianita_indrawati@yahoo.com
}

\begin{abstract}
Abstrak
Tulisan ini membahas proses fonologis dalam pengadopsian beberapa kata bahasa Indonesia ke dalam bahasa Ciacia di kabupaten Buton, provinsi Sulawesi Tenggara. Bahasa Ciacia yang merupakan salah satu bahasa dengan penutur terbesar di daratan Buton Raya dalam perkembangannya banyak mengadopsi beberapa kata bahasa Indonesia. Pengadopsian kata dalam bahasa Indonesia paling banyak dibandingkan dengan kata dari bahasa daerah lain. Hal ini disebabkan suku Ciacia hanya terbiasa mencampur kedua bahasa tersebut dalam kesehariannya. Dalam pengadopsian kata bahasa Indonesia ke dalam bahasa Ciacia banyak yang mengalami proses fonologis. Proses fonologis yang paling banyak ditemukan adalah penambahan dan penghilangan bunyi di akhir kata. Kata yang telah diadopsi ke dalam bahasa Ciacia selalu berupa kata dengan suku kata terbuka. Hal ini disebabkan oleh dalam bahasa Ciacia tidak dikenal kata dengan suku tertutup.
\end{abstract}

Kata Kunci: proses fonologis, anaptiksis, zeroisasi, bahasa Ciacia

\begin{abstract}
This paper discusses the adoption of several phonological processes in Indonesian words into Ciacia in Buton, Southeast Sulawesi province. Ciacia language which is one of the languages with the most speakers in mainland Buton Kingdom in its development are adopting some Indonesian words. Adoption of words in Indonesian as compared to most other areas of the language word. This is due to ethnic mixing Ciacia just used both languages in daily life. In adopting Indonesian words into Ciacia many who have phonological processes. Phonological processes are most commonly found is the addition and removal of noise at the end of the word. The word has been adopted into the language Ciacia always be words with open syllables. This is caused by the language Ciacia unknown words with closed syllables.
\end{abstract}

Keywords: phonological process, anapticsis, zeroization, Ciacia language 


\section{PENDAHULUAN}

Bahasa Ciacia (yang selanjutnya disingkat BC) merupakan salah satu bahasa daerah yang digunakan di Pulau Buton, Sulawesi Tenggara. Secara dialektologis BC terdiri atas lima dialek, yakni (1) dialek Lapandewa; (2) dialek Kancina; (3) dialek Masiri; (4) dialek Gonda Baru; dan (5) dialek Kumbewaha. Di samping itu, BC merupakan bahasa dengan persentase perbedaan yang berkisar antara 85-91\% (Pusat Bahasa, 2008). Selain BC, di Kabupaten Buton terdapat juga daerah sebaran bahasa Muna; bahasa Lasalimu-Kamaru; bahasa Sasak. Saat ini Bc termasuk bahasa daerah di Buton yang memiliki jumlah penutur terbesar. Biarpun sampai sekarang BC belum memiliki aksara resmi, namun upaya pelestarian $\mathrm{BC}$ terus dilakukan, misalnya upaya menentukan aksara yang tepat untuk BC, pendokumentasian BC (penyusunan kamus BC), dan lain-lain.

Beberapa penelitian tentang BC sudah dilakukan oleh para peneliti sebelumnya. Namun, mayoritas penelitian tersebut berfokus pada masalah adaptasi (Song, 2013), ancaman kepunahan (Azhar, 2011), dan genealogi bahasa (Hanan, 2014). Perhatian terhadap proses fonologis BC belum banyak dilakukan oleh para pemerhati bahasa ini. Dengan alasan tersebut, tulisan ini berusaha memfokuskan diri pada proses fonologis bahasa BC.

Penutur BC dalam komunikasi sehari-hari terbiasa menggunakan BC dan bahasa Indonesia (yang selanjutnya disingkat BI). Pencampuran kedua bahasa $\mathrm{BC}$ dan $\mathrm{BI}$ ini sangatlah wajar karena penutur $\mathrm{BC}$ umumnya penutur yang berdwibahasa. Kondisi ini dapat ditemukan di daerah sebaran BC baik yang ada di dataran tinggi dan di pesisir. Kemajuan teknologi dan pemerataannya menyebabkan arus informasi mudah diakses bahkan oleh penutur BC yang ada di daerah terpencil. Hal ini disebabkan hampir setiap rumah penutur BC memiliki alat transmisi (parabola) untuk mengakses informasi dari luar Buton. Kenyataan inilah yang juga mengakibatkan terjadinya diserapnya beberapa kata dalam BI ke dalam BC. Proses pengadosian beberapa kata BI ke dalam BC ini 
memiliki kekhasan. Kekhasan dan keunikan yang ditemukan secara fonologis inilah yang akan diuraikan dalam tulisan ini. Masalah penelitian ini adalah proses fonologis yang terjadi dalam pengadopsian kata-kata dalam BI ke dalam BC. Selanjutnya, Tujuan penelitian ini adalah menjelaskan proses fonologis yang terjadi dalam pengadopsian kata-kata dalam BI ke dalam BC.

\section{Kerangka Teori}

Teori yang dipakai dalam penelitian ini adalah teori perubahan bunyi. Bunyi-bunyi lingual condong berubah karena lingkungannya. Dengan demikian, perubahan bunyi tersebut bisa berdampak pada dua kemungkinan. Apabila perubahan itu tidak sampai membedakan makna atau mengubah identitas fonem, maka bunyi-bunyi tersebut masih merupakan alofon atau varian bunyi dari fonem yang sama. Dengan kata lain. perubahan itu masih dalam lingkup perubahan fonetis. Tetapi, apabila perubahan bunyi itu sudah sampai berdampak pada pembedaan makna atau mengubah identitas fonem, maka bunyi-bunyi tersebut merupakan alofon dari fonem yang berbeda. Dengan kata lain, perubahan itu disebut sebagai perubahan fonemis. Jenis-jenis perubahan bunyi Jenis-jenis perubahan bunyi tersebut berupa: 1) asimilasi, 2) disimilasi, 3) modifikasi vokal, 4) netralisasi, 5) zeroisasi, 6) metatesis, 7) diftongisasi, 8) monoftongisasi, dan 9) anaptiksis (Keraf, 1994). Akan tetapi, hanya perubahan bunyi yang ditemukan dalam penelitian ini saja yang akan dibahas, yaitu zeroisasi dan anaptiksis. Zeroisasi adalah penghilangan bunyi fonemis sebagai akibat upaya penghematan atau ekonomisasi pengucapan. Peristiwa ini biasa terjadi pada penuturan bahasa-bahasa di dunia, termasuk bahasa Indonesia, asal saja tidak mengganggu proses dan tujuan komunikasi. Peristiwa ini terus berkembang karena secara diam-diam telah didukung dan disepakati oleh komunitas penuturnya.

Dalam bahasa Indonesia sering dijumpai pemakaian kata tak atau ndak untuk tidak, tiada untuk tidak ada, gimana untuk bagaimana, tapi untuk tetapi. 
Padahal, penghilangan beberapa fonem tersebut dianggap tidak baku oleh tatabahasa baku bahasa Indonesia. Tetapi, karena demi kemudahan dan kehematan, gejala itu terus berlangsung. Apabila diklasifikasikan, zeroisasi ini paling tidak ada tiga jenis, yaitu aferesis, apokop, dan sinkop.

1) Aferesis adalah proses penghilangan atau penanggalan satu atau lebih fonem pada awal kata.

2) Apokop adalah proses penghilangan atau penanggalan satu atau lebih fonem pada akhir kata.

3) Sinkop adalah proses penghilangan atau penanggalan satu atau lebih fonem pada tengah kata.

Perubahan bunyi berikutnya adalah anaptiksis. Anaptiksis adalah perubahan bunyi dengan jalan menambahkan bunyi vokal tertentu di antara dua konsoanan untuk memperlancar ucapan. Adapun jenis anaptiksis aadalah protesis. Protesis adalah proses penambahan atau pembubuhan bunyi pada awal kata.

1) Epentesis adalah proses penambahan atau pembubuhan bunyi pada tengah kata.

2) Paragog adalah proses penambahan atau pembubuhan bunyi pada akhir kata.

\section{Metode Penelitian}

Sumber data penelitian ini adalah semua tuturan dari informan. Adapun datanya adalah tuturan-tuturan (berian-berian) yang telah ditetapkan glosnya (padanannya dalam bahasa Indonesia). Selain itu, digunakan model pertanyaan tentang "kehidupan sehari-hari" atau "cara membuat sesuatu". yang digunakan sebagai penunjang untuk melakukan cek silang antara berian yang terdapat dalam instrumen dan penerapannya dalam berbicara secara bebas. Selanjutnya, penetapan DP menggunakan sebagian daerah-daerah yang telah ditetapkan 
sebagai dialek oleh Pusat Bahasa, yakni di (1) Lapandewa; (2) Masiri; dan (3) Sorawolia. Pemilihan DP di daerah itu dilakukan sesuai dengan kondisi kebahasaan yang ada dan ketersebaran lokasi.

Teknik pengumpulan data yang digunakan dalam penelitian ini adalah teknik simak libat cakap dan teknik angket/kuesioner. Teknik simak libat cakap digunakan dengan cara berinteraksi langsung dengan informan untuk mendapatkan data berian yang terdapat dalam angket/kueisoner yang berupa daftar tanyaan sebanyak 800 glos.

Penganalisisan data penelitian ini dilakukan dengan cara mengamati proses perubahan bunyi yang ada pada data BC yang tergolong sebagai kata serapan dari BI. Selanjutnya, diuraikan tentang proses perubahan bunyi yang terjadi dan kaidahnya.

\section{PEMBAHASAN}

Proses fonologis terjadi dalam proses pengadopsian BI ke dalam BC. Proses yang berupa perubahan bunyi dan umumnya terjadi adalah perubahan bunyi jenis Protesis, Apokof, dan Paragog. Berikut ini diuraikan masing-masing perubahan bunyi tersebut.

\section{Protesis}

Protesis merupakan perubahan bunyi akibat penambahan bunyi pada awal kata. Perubahan bunyi jenis protesis ini ditemukan dalam beberapa kata BC yang merupakan adopsi dari BI. Kata-kata tersebut diuraikan berikut ini.

\begin{tabular}{|c|c|}
\hline Glos/BI & $B C$ \\
\hline kati & $\frac{\sigma \& \sigma}{x}$ \\
\hline panas & $\begin{array}{l}\text { லロ } \\
\text { б }\end{array}$ \\
\hline kita & $\begin{array}{l}\text { (x\& }) \\
\sigma \Leftrightarrow \text { H }\end{array}$ \\
\hline
\end{tabular}




\section{\&)}

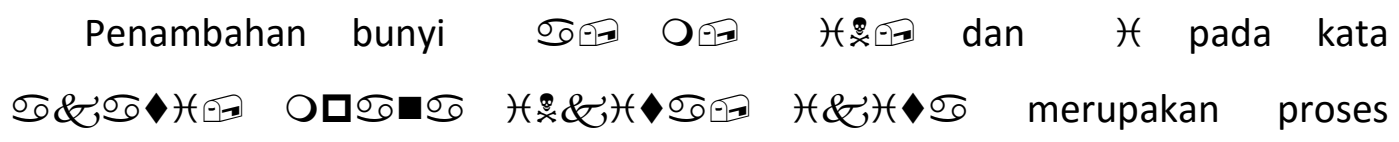
protesis yang terjadi dalam kata serapan BC dari BI. Dalam hal ini tidak hanya bunyi vokal, bunyi konsonanpun memiliki peluang untuk ditambahkan di awal kata dalam beberapa pengadosian kata-kata tertentu.

\section{Paragog}

Proses fonologis yang berupa perubahan bunyi berikutnya adalah paragog. Paragog merupakan proses penambahan bunyi di akhir kata. Berikut ini beberapa kata BC yang diadopsi dari BI.

\begin{tabular}{|c|c|}
\hline Glos/BI & $B C$ \\
\hline sandal & $\begin{array}{l}\sigma \sigma \Omega \sigma \\
\text { - } t\end{array}$ \\
\hline mandor & 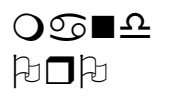 \\
\hline sopir & 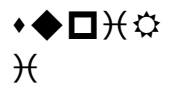 \\
\hline cangkir & 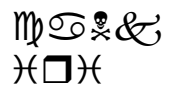 \\
\hline pikir & $\begin{array}{l}\square)(\&) x \\
\square)\end{array}$ \\
\hline kasar & $\begin{array}{l}\text { \&ठஏ } \\
\square \sigma\end{array}$ \\
\hline $\begin{array}{l}\text { obor } \\
\text { balas }\end{array}$ & $\begin{array}{l}\square \Omega \square \square \\
\text { pe }\end{array}$ \\
\hline kasar & 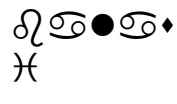 \\
\hline & 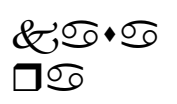 \\
\hline
\end{tabular}


Penambahan bunyi di akhir kata dalam proses pengadosian beberapa kata dalam BI ke dalam BC. Hal ini disebabkan oleh dalam BC tidak dikenal suku kata tertutup sehingga jika ada kata yang diadopsi atau diserap merupakan kata dengan suku tertutup maka dalam BC mendapat penambahan bunyi vokal.

\section{Apokof}

Apokof merupakan salah satu jenis perubahan bunyi jenis Zeroisasi. Perubahan bunyi yang terjadi akibat dari pengkilangan satu bunyi di akhir kata ini terjadi juga dalam proses pengadopsian BI ke dalam BC. Berikut ini beberapa kata BC yang merupakan adopsi atau serapan dari BI.

\begin{tabular}{|c|c|}
\hline Glos/BI & $\mathrm{BI}$ \\
\hline jambang & 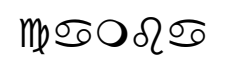 \\
\hline songkok & 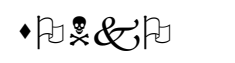 \\
\hline kutang & $\& \diamond \sigma$ \\
\hline lalat & • \\
\hline tanduk & $\nabla \sigma \Omega$ \\
\hline daging & $\Omega \sigma b_{0} t$ \\
\hline santan & • $\sigma \square$ \\
\hline durian & $\Omega \diamond \square)(\triangle \sigma$ \\
\hline pandan & 口的 $\Omega \sigma$ \\
\hline sawah & • \\
\hline gunung & $y_{0} \diamond \nabla$ \\
\hline langit & - $\sigma x$ \\
\hline bulan & $\bullet \bullet \sigma$ \\
\hline piring & $\square)(\square)($ \\
\hline bajak & 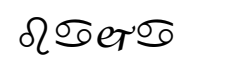 \\
\hline
\end{tabular}




\begin{tabular}{|c|c|}
\hline arit & $\sigma$ \\
\hline sabit & - $\sigma \Omega)$ \\
\hline golok & 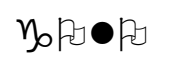 \\
\hline cangkul & 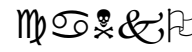 \\
\hline lesung & $\bullet$ 的・ \\
\hline pusing & 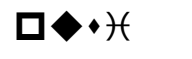 \\
\hline bungkuk & $\Omega \diamond: \& \mathcal{X}$ \\
\hline tembak & $\diamond 0 \Omega \sigma$ \\
\hline salah & • ஏூర \\
\hline
\end{tabular}

Seperti halnya pengambahan bunyi di akhir kata (paragog), proses penghilangan bunyi di akhir kata yang diserap atau diadopsi ke dalam BC merupakan salah satu bukti bahwa dalam BC tidak ditemukan kata dengan suku tertutup. Oleh karena itu, jika dalam kata yang diserap atau diadopsi merupakan kata yang memiliki suku tertutup, maka alternatif perubahan bunyinya adalah penambahan bunyi vokal (paragog) atau penghilangan bunyi konsonan di akhir kata (apokof). Apokof dapat dilihat dibeberapa kata yang diuraikan di atas.

\section{SIMPULAN}

Dengan mempertimbangkan hasil dari proses fonologis yang berupa perubahan bunyi yang terjadi dalam beberapa kata serapan $\mathrm{BI}$ ke dalam $\mathrm{BC}$, dapat ditarik sebuah kesimpulan bahwa proses tersebut adalah proses protesis, paragog, dan perubahan bunyi jenis zeroisasi yang berupa apokof. Melalui protesis, paragog, dan zeroisasi, proses penghilangan bunyi di akhir kata yang diserap atau diadopsi ke dalam BC merupakan salah satu bukti bahwa dalam BC tidak ditemukan kata dengan suku tertutup. 


\section{DAFTAR PUSTAKA}

Azhar, Iqbal Nurul. 2011. "Saat-saat Kritis Bahasa Cia-Cia" dalam Jurnal Prosodi, Volume V, Nomor 2, Juli.

Hanan, Sandra Safitri. 2014. Genealogi Bahasa Cia- Cia. Yogyakarta: Universitas Gadjah Mada.

Keraf, Gorys. 1994. Linguistik bandingan Historis. Jakarta: Gramedia Pustaka Utama.

Pusat Bahasa. 2008. Bahasa dan Peta Bahasa di Indonesia. Jakarta: Pusat Bahasa. Song, Seung-Wong. 2013. "Being Korean in Buton? The Cia-Cia's Adoption of the Korean Alphabet and Identity Politics in Decentralized Indonesia" dalam Jurnal Kemanusiaan, Volume 20, No. 1, 51-80. 